\title{
Effects of static magnetic field exposure on antioxidative enzymes activity and DNA in rat brain
}

\author{
Salem Amara ${ }^{1,2,3}$, Thierry Douki ${ }^{3}$, Catherine Garel ${ }^{2}$, Alain Favier ${ }^{2,3}$, Mohsen Sakly $^{1}$, Khémais \\ B. Rhouma ${ }^{1}$ and Hafedh Abdelmelek ${ }^{1}$ \\ ${ }^{1}$ Laboratoire de Physiologie Animale, Faculté des Sciences de Bizerte, 7021 Jarzouna, Tunisia \\ ${ }^{2}$ Laboratoire de Stress Oxydant, Département de Biologie Intégrée, CHU-Grenoble, France \\ ${ }^{3}$ Commissariat d'Energie Atomique DRFMC/SCIB, Laboratoire des Lésions des Acides Nucléiques, Grenoble, France
}

\begin{abstract}
The present study was undertaken in order to investigate the effects of static magnetic field (SMF) exposure on the antioxidative enzymes activity, malondialdehyde (MDA) concentration and DNA oxidation in male rat brain. The exposure of rats to SMF (128 mT, $1 \mathrm{~h} /$ day during 30 consecutive days) decreased the glutathione peroxidase (GPx; $-39 \%, p<0.05$ ), CuZn superoxide dismutase (CuZn-SOD; $-35 \%, p<0.05)$ and catalase $(-59 \%, p<0.05)$ activities in frontal cortex. The same treatment decreased the CuZn-SOD $(-51 \%, p<0.05)$ and Mn-SOD $(-13 \%, p<0.05)$ activities in hippocampus. However, the glutathione levels remained unchanged in the both brain structures. In the hippocampus, SMF exposure increased MDA concentration $(+32 \%, p<0.05)$. Interestingly, exposed-rats to SMF displayed a significant increase of metallothioneins level in frontal cortex $(+100 \%, p<0.05)$, while the 8-oxo-7,8-dihydro-2'-deoxyguanosine (8-oxodGuo) concentration remained unaffected, indicating the absence of DNA oxidation.

Our results indicated that sub-chronic exposure to SMF induced oxidative stress in rat hippocampus and frontal cortex. Metallothionein induction protected probably DNA against oxidative damage.
\end{abstract}

Key words: Static magnetic field - Frontal cortex - Hippocampus - Oxidative stress - Rat

\section{Introduction}

Previous data suggested the association between electromagnetic field (EMF) exposure and the increased incidence of certain types of tumour, particularly leukemia and brain cancer (Wertheimer et al. 1995; Aldrich et al. 2001). Moreover, EMF can induce biochemical changes, which are the result of altered membrane potential, and consequently perturbed function of the transmembrane ionic and cell activities (Berg 1993). Prina-Mello et al. (2006) reported that static magnetic field (SMF) exposure activated a voltage dependent $\mathrm{Ca}^{2+}$ channel opening in rat cortical neurons. Previous data pointed that SMF could modulate synaptic excitability as measured in mouse hippocampal slice preparations (Trabulsi et al. 1996; Wieraszko 2000; Bailey 2002). Recently, Abdelme-

Correspondence to: Amara Salem, Laboratoire de Physiologie Animale, Faculté des Sciences de Bizerte, 7021 Jarzouna, Tunisia E-mail: amara_salem_fsb@yahoo.fr lek et al. (2006) reported that SMF (128 mT) increased the norepinephrine content in skeletal muscle associated to sympathetic hyperactivity in rats. Previous reports from our laboratory demonstrated that sub-acute exposure to SMF stimulated biosynthesis of plasma corticosterone and metallothionein in female rats and enhanced apoptosis. In part, the mechanism for this stress response by SMF is believed to be related to oxidative stress (Chater et al. 2004, 2005). The nervous system including the brain, spinal cord, and peripheral nerves is rich in both unsaturated fatty acids and iron. The high lipid content of nervous tissue, coupled with its high aerobic metabolic activity, makes it particularly susceptible to oxidative damage (Bauer et al. 1999).

Biological systems can respond to a wide range of SMF. Some of these responses seem to be mediated partly through free radical reactions. However, health and environmental concerns have been raised because the SMF effects on oxidative stress leading to genetic mutation and apoptosis/necrosis have been found (Okano 2008). Moreover, Hashish et al. 
(2008) indicate that there is a relation between the exposure to SMF and the oxidative stress through distressing redox balance leading to physiological disturbances. It is recorded that after exposure to magnetic field mainly superoxide anion radicals were produced, both in mouse bone marrow-derived macrophages and also in their precursor cells (Rollwitz et al. 2004). Recently, marked increases in the levels of malondialdehyde (MDA) and 8-oxo-7,8-dihydro-2'-deoxyguanosine (8-oxodGuo), oxidative products of lipids and DNA respectively, and xanthin oxidase activity in brain tissues and plasma were recorded after magnetic field exposure (Wolf et al. 2005; Yokus et al. 2005).

The increasing production of magnetic fields, due to the expanding use of electronic devices in normal life, is encouraging studies on the effects of magnetic field on living organisms, with a view to better protecting human health against their probable unfavourable effects. The present study performed an experimental approach to investigate the effects of sub-chronic exposure to SMF on antioxidative response and DNA damage in rat frontal cortex and hippocampus.

\section{Materials and Methods}

\section{Animals}

Adult Wistar male rats (SIPHAT, Tunisia), weighing 180$200 \mathrm{~g}$ were randomly divided into control rats $(n=6)$ and SMF-exposed rats $(n=6)$. Animals were housed in group of six in cages at $25^{\circ} \mathrm{C}$, under a $12: 12$ light/dark cycle, with free access to water and commercial wash.

Animals were cared for, under the Tunisian code of practice for the Care and Use of Animals for Scientific Purposes. The experimental protocols were approved by the Faculty Ethics Committee (Faculté des Sciences de Bizerte, Tunisia).

\section{Exposure system}

Electromagnets (EM4-HV, Magnet Power supply Model 647; Lake Shore Cryotronic, Inc., Westerville Ohio, USA) are compact electromagnets suited for many applications such as magnetic resonance demonstrations. Water-cooled coils provide excellent field stability and uniformity (when high power is required to achieve the maximum field capability for the electromagnet). The Lake Shore electromagnets generate a SMF (Abdelmelek et al. 2006).

\section{SMF exposure}

The intensity of SMF was measured and standardized in the total floor area of the plexiglas cage at $128 \mathrm{mT}$. The cage was
$20 \mathrm{~cm}$ long, $10 \mathrm{~cm}$ wide and $20 \mathrm{~cm}$ high. The two bobbins of the Lake Shore system were separated by $12 \mathrm{~cm}$. Male rats were exposed to the SMF, $1 \mathrm{~h} /$ day (between 9-12 h) during 30 consecutive days. The cage in the Lake Shore contained two rats for each assay. The control rats were placed in the same conditions without applying the SMF.

\section{Tissue preparation}

After 4 weeks of exposure both groups were sacrificed and brains were immediately excised. Samples of frontal cortex and hippocampus were weighed, rinsed with ice-cold deionized water and dried with filter paper. Tissues fractions were homogenized using the appropriate buffer (Tris $10 \mathrm{mmol} / \mathrm{l}$, EDTA $1 \mathrm{mmol} / \mathrm{l}$, PMSF $1 \mathrm{mmol} / \mathrm{l}$; $\mathrm{pH}=7.5$ ). The homogenates were centrifuged at $600 \times g$ for $10 \mathrm{~min}$ and recentrifuged at $13,000 \times g$ for $20 \mathrm{~min}$ at $4^{\circ} \mathrm{C}$ to obtain a postnuclear homogenate and postmitochondrial supernatant fractions (Ebru and Mesut 2002).

\section{MDA assay}

Lipid peroxidation in the tissues was measured by the TBARS (thiobarbituric acid reacting substance) and was expressed in terms of MDA content (Placer et al. 1966). Sample aliquots were incubated with $10 \%$ trichloroacetic acid and $0.67 \%$ thiobarbituric acid. The mixture was heated on a boiling water bath for $30 \mathrm{~min}$, an equal volume of n-butanol was added, and the final mixture was centrifuged; the organic phase was collected for fluorescence measurements. Samples assayed for MDA contained $1 \mathrm{mmol} / \mathrm{l} \mathrm{BHT}$ (butylated hydroxytoluene) in order to prevent artefactual lipid peroxidation during the boiling step. The absorbance of samples was determined at $532 \mathrm{~nm}$. Results were expressed as micromoles MDA per gram of protein.

\section{Glutathione peroxidase activity}

The reaction was carried out at $25^{\circ} \mathrm{C}$ in $600 \mu \mathrm{l}$ of solution containing $100 \mathrm{mmol} / \mathrm{l}$ of potassium phosphate buffer, $\mathrm{pH}$ 7.7, $1 \mathrm{mmol} / \mathrm{l}$ of ethylenediaminetetraacetic acid, $0.4 \mathrm{mmol} / \mathrm{l}$ of sodium azide, $2 \mathrm{mmol} / \mathrm{l}$ of glutathione, $0.1 \mathrm{mmol} / \mathrm{l}$ of nicotinamide adenine dinucleotide phosphate, and $0.62 \mathrm{U}$ of glutathione reductase. The activity of glutathione peroxidase (GPx) was assayed by the subsequent oxidation of NADPH at $340 \mathrm{~nm}$ with $t$-butyl hydroperoxide as a substrate (Maral et al. 1977).

\section{Catalase activity}

Catalase activity was measured at $20^{\circ} \mathrm{C}$ according to Aebi (1984). The homogenate was incubated with ethanol (10\%) and Triton (10\%). Activity was assayed at $25^{\circ} \mathrm{C}$ by determin- 
ing the rate of degradation of $\mathrm{H}_{2} \mathrm{O}_{2}$ at $240 \mathrm{~nm}$ in $10 \mathrm{mmol} / \mathrm{l}$ of potassium phosphate buffer $(\mathrm{pH}$ 7.0). The extinction coefficient of $43.6 \mathrm{mmol} \cdot \mathrm{l}^{-1} / \mathrm{cm}$ was used for calculation. One unit is defined as 1 pmol of $\mathrm{H}_{2} \mathrm{O}_{2}$ consumed per minute and the specific activity is reported as units per milligram of protein.

\section{Superoxide dismutase activity}

The method described by Paoletti and Macoli (1990) was used for the assay of superoxide dismutase (SOD) activity. This method consists of purely chemical reactions sequence, which generates superoxide from molecular oxygen in the presence of EDTA, manganese(II) chloride and mercaptoethanol.

\section{Measure of metallothioneins}

The determination of metallothioneins was performed according to the technique described by Eaton and Cherian (1991).

\section{DNA extraction from frontal cortex and HPLC-EC analysis}

DNA was extracted using a previously reported chaotropic method that prevents spurious oxidation of DNA bases (Ravanat et al. 2002). Tissues samples were weighted and each portion was homogenized in $1.2 \mathrm{ml}$ of buffer $(320 \mathrm{mmol} / \mathrm{l}$ sucrose, $10 \mathrm{mmol} / 1$ Tris, $5 \mathrm{mmol} / 1 \mathrm{MgCl}_{2}, 0.1 \mathrm{mmol} / 1$ desferroxamine mesylate, $1 \%$ Triton, $\mathrm{pH} 7.5)$. After centrifugation, the DNA pellet was rinsed by $1 \mathrm{ml}$ of $70 \%$ ethanol. The DNA

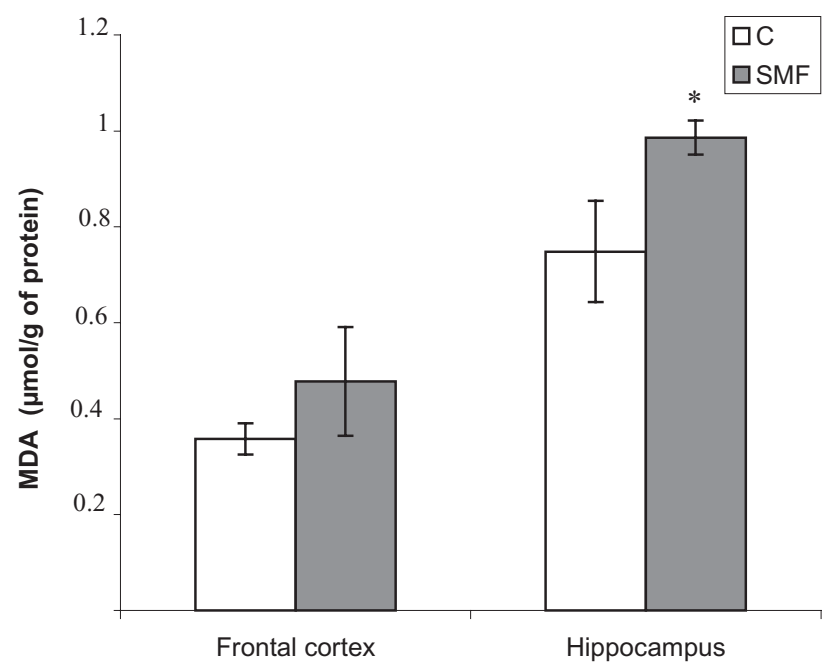

Figure 1. Effects of static magnetic field (SMF) exposure on malondialdehyde (MDA) concentration in rat frontal cortex and hippocampus. Data represent the means \pm SEM of 6 animals per group. ${ }^{\star} p<0.05$, compared to control (C). pellet was then solubilized into $100 \mu \mathrm{l}$ of deionised water containing $0.1 \mathrm{mmol} / \mathrm{l}$ deferroxamine mesylate. The DNA solution was incubated with 2 units of nuclease P1, the sample was held at $37^{\circ} \mathrm{C}$ for $2 \mathrm{~h}$. Then, 4 units of alkaline phosphatase were added together with palk buffer (Douki et al. 2000). After incubation $1 \mathrm{~h}$ at $37^{\circ} \mathrm{C}$, the samples were centrifuged and the aqueous layer collected and analysed by HPLC-EC detection. The resulting solution contained normal bases and 8-oxodGuo as nucleosides. The procedure described by Kasai (1997) was applied for the measurement of the 8-oxodGuo. Separation of nucleosides was performed using a C18 reversed-phase Uptisphere ODB octadecylsilyl silica gel column $(5 \mu \mathrm{m}, 4.6 \times 250 \mathrm{~mm})$ from Iterchim (Montluçon, France) maintained at $30^{\circ} \mathrm{C}$. The retention time of 8 -oxodGuo is $21.5 \mathrm{~min}$. The amount of DNA analysed was determined from the area of the peak of 8-oxodGuo after appropriate calibration. A Coulochem II. model $5200 \mathrm{~A}$, electrochemical detector (ESA, Chemlsford, MA, USA) was used for the detection of 8-oxodGuo. Elution of unmodified nucleosides was monitored using an UV detector (model 2151, LKB Bromma) set at $280 \mathrm{~nm}$.

\section{Data presentation and statistical analysis}

Data were analysed using Stat View $512^{+}$software (Abacus Concept Inc.). Means were given with \pm SEM and were subjected to the unpaired Student's $t$-test. The level of significance was set at $p<0.05$.

\section{Results}

Effects of SMF exposure on the antioxidant enzymes and MDA concentration in hippocampus

In the hippocampus, the CuZn-SOD and the Mn-SOD activities were found to be decreased by SMF expose respectively (7.29 \pm 0.78 vs. $14.9 \pm 0.63 \mathrm{U} / \mathrm{mg}$ protein (pt), $p<0.05 ; 6.26$ \pm 0.28 vs. $7.17 \pm 0.3 \mathrm{U} / \mathrm{mg}$ pt, $p<0.05$ ) (Table 1 ). However, catalase activity $(1.51 \pm 0.29 v s .1 .74 \pm 0.55 \mathrm{U} / \mathrm{mg} \mathrm{pt}, p>0.05)$ and glutathione level $(12.79 \pm 1.35$ vs. $12.01 \pm 4.21 \mathrm{U} / \mathrm{mg}$ pt, $p>0.05$ ) remained unchanged (Table 1). SMF exposure increased MDA level $(0.98 \pm 0.03$ vs. $0.74 \pm 0.10 \mu \mathrm{mol} / \mathrm{g} \mathrm{pt}$, $p<0.05$ ) in hippocampus (Figure 1).

Effects of SMF exposure on antioxidant response and DNA damage in frontal cortex

Following sub-chronic exposure to SMF, we noted a decrease of the CuZn-SOD (8.09 $\pm 0.44 v s .12 .49 \pm 1.12 \mathrm{U} / \mathrm{mg}$ pt, $p<$ $0.05)$, the GPx $(130.16 \pm 13.45$ vs. $213.8 \pm 22.83 \mathrm{U} / \mathrm{mg} \mathrm{pt}$, $p<0.05)$ and catalase $(1.52 \pm 0.09$ vs. $2.55 \pm 0.27 \mathrm{U} / \mathrm{mg}$ pt, $p<0.05)$ activities in frontal cortex of rats. However, SMF 
had no effect on catalase activity $(1.52 \pm 0.09 v s .2 .55 \pm 0.27$ $\mathrm{U} / \mathrm{mg} \mathrm{pt}, p>0.05)$ and glutathione level $(11.35 \pm 1.16 \mathrm{vs}$. $12.15 \pm 4.02 \mathrm{U} / \mathrm{mg} \mathrm{pt}, p>0.05$ ) (Table 1). Moreover, SMF exposure failed to alter MDA concentration $(0.47 \pm 0.11 \mathrm{vs}$. $0.35 \pm 0.03 \mu \mathrm{mol} / \mathrm{g} \mathrm{pt}, p>0.05$ ) (Figure 1).

SMF exposure increased the level of metallothioneins in frontal cortex of rats $(0.31 \pm 0.07$ vs. $0.15 \pm 0.03 \mu \mathrm{g} / \mathrm{g}$, $p<0.05$ ) (Figure 2). By contrast, the 8-oxodGuo concentration remained unchanged $(1.78 \pm 0.29$ vs. $1.67 \pm 0.08$ 8 -oxodGuo/ $10^{6}$ bases, $p>0.05$ ) (Figure 3 ).

\section{Discussion}

The major finding of our study reported that sub-chronic exposure to SMF (128 mT, $1 \mathrm{~h}$ /day during 30 consecutive days) induced oxidative stress in rat hippocampus and frontal cortex. By contrast, the same treatment failed to induce DNA oxidation.

Antioxidant enzymes are considered to be a primary defence that prevents biological macromolecules from oxidative damage. SOD is mainly located in neurons whereas $\mathrm{GPx}$, the major protective enzyme against the action of $\mathrm{H}_{2} \mathrm{O}_{2}$, is mostly present in astrocytes (Benzi and Moretti 1995). Among these antioxidants, SOD is critically important in brain (Benzi and Moretti 1995). Reports related to the effect of SMF on free radical scavenging systems are very limited till date. In the present investigation, we examined the effect of sub-chronic exposure to SMF in activities of SOD, GPx, catalase and glutathione levels in hippocampus and frontal cortex of rats. Our results show that SMF decreased the GPx (-39\%), CuZn-SOD $(-35 \%)$ and catalase $(-59 \%)$ activities in frontal cortex and those of CuZn-SOD (-51\%) and MnSOD $(-13 \%)$ in hippocampus. By contrast, SMF exposure increased the MDA $(+32 \%)$ level in hippocampus. Thus, the increase of MDA concentration following SMF application could be explained by the induction of lipid peroxidation in hippocampus which might be related to the inhibition of SOD (Nehru and Anand 2005). The decrease of antioxidant enzymes activity associated to a lipid peroxidation indicated that SMF exposure induced an oxidative stress in brain. The

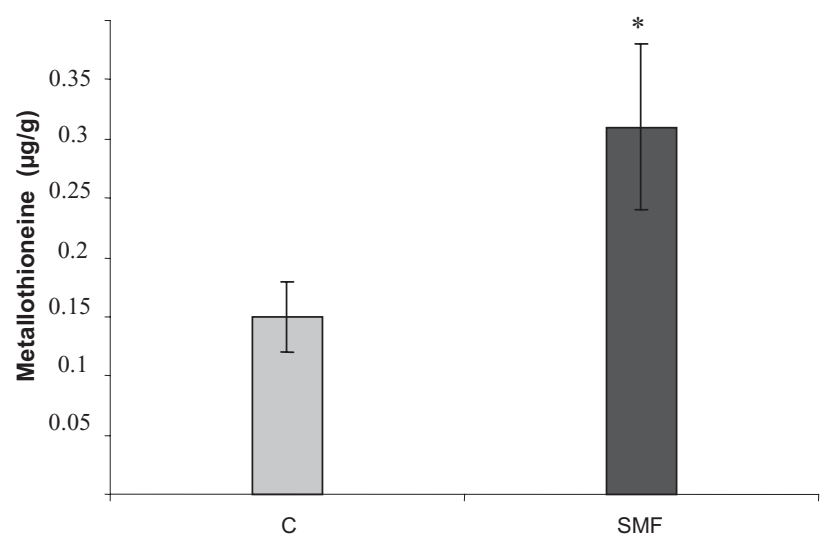

Figure 2. Effects of static magnetic field (SMF) exposure on metallothionein concentration in rat frontal cortex. Data represent the means \pm SEM of 6 animals per group. ${ }^{*} p<0.05$, compared to control C.

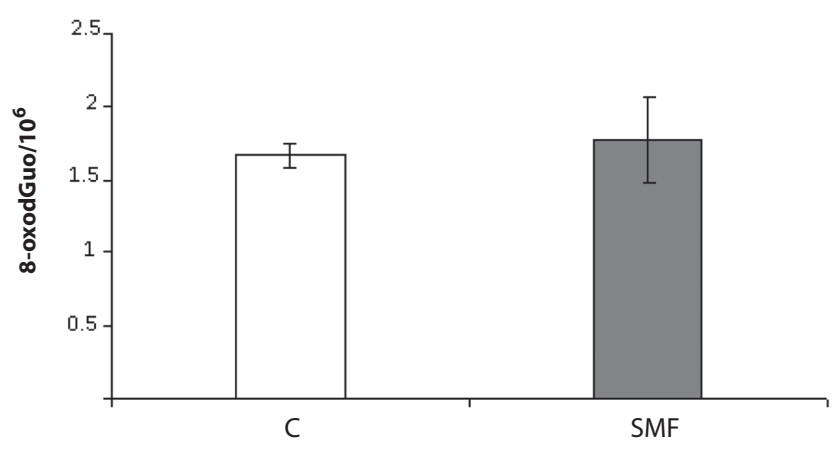

Figure 3. Effects of static magnetic field (SMF) exposure on 8-oxo7,8-dihydro-2'-deoxyguanosine (8-oxodGuo) concentration in rat frontal cortex. Data represent the means \pm SEM of 6 animals per group. C, control.

mechanism implicated is not well understood. Two possible explanations at least may be advanced. Firstly, SMF exposure induced probably the perturbation of cerebral mineral divalent elements homeostasis, contributing to their deficiency in the tissue. In accord with this view data

Table 1. Effects of SMF exposure on the antioxidant enzymes activity and glutathione levels in frontal cortex and hippocampus of rats

\begin{tabular}{|l|l|c|c|c|c|c|}
\hline \multicolumn{2}{|c|}{} & \multicolumn{1}{c|}{$\begin{array}{c}\text { GPx } \\
(\mathrm{U} / \mathrm{mg} \mathrm{pt})\end{array}$} & $\begin{array}{c}\text { CAT } \\
(\mathrm{U} / \mathrm{mg} \mathrm{pt})\end{array}$ & $\begin{array}{c}\text { CuZn-SOD } \\
(\mathrm{U} / \mathrm{mg} \mathrm{pt})\end{array}$ & $\begin{array}{c}\text { Mn-SOD } \\
(\mathrm{U} / \mathrm{mg} \mathrm{pt})\end{array}$ & $\begin{array}{c}\text { Glutathione } \\
(\mathrm{U} / \mathrm{mg} \mathrm{pt})\end{array}$ \\
\hline \multirow{2}{*}{ Frontal cortex } & $\mathrm{C}$ & $213.8 \pm 22.83$ & $2.55 \pm 0.27$ & $12.49 \pm 1.12$ & $4.31 \pm 0.27$ & $12.15 \pm 4.02$ \\
\cline { 2 - 7 } & SMF & $130.16 \pm 13.45^{*}$ & $1.52 \pm 0.09^{*}$ & $8.09 \pm 0.44^{*}$ & $3.78 \pm 0.07$ & $11.35 \pm 1.16$ \\
\hline \multirow{2}{*}{ Hippocampus } & $\mathrm{C}$ & $190 \pm 36.97$ & $1.74 \pm 0.55$ & $14.9 \pm 0.63$ & $7.17 \pm 0.3$ & $12.01 \pm 4.21$ \\
\cline { 2 - 7 } & SMF & $140.8 \pm 6.47$ & $1.51 \pm 0.29$ & $7.29 \pm 0.78^{*}$ & $6.26 \pm 0.28^{*}$ & $12.79 \pm 1.35$ \\
\hline
\end{tabular}

Data represent the means \pm SEM of 6 animals per group. ${ }^{\star} p<0.05$, compared to control C. SMF, static magnetic field; GPx, glutathione peroxidase; CAT, catalase; SOD, superoxide dismutase; pt, protein. 
indicated that EMF-exposure induced a zinc deficiency in tissues (Ozturk et al. 2003; Amara et al. 2007). Previously, it was shown that zinc deficiency induced oxidative stress in rat brain (Yousef et al. 2002). Interestingly, we have shown in our laboratory that zinc administration prevents hematological and biochemical alterations induced by SMF in rats (Amara et al. 2005). Secondly, SMF exposure could be followed by cerebral free radical production (Lee et al. 2004). Brain is very vulnerable to reactive oxygen species because it contains high concentrations of easily peroxidizable fatty acid and iron (Bauer et al. 1999; Lee et al. 2004). Previous data reported also that magnetic field exposure affects iron homeostasis in certain cells, leading to an increase in free iron in the cytoplasm and nucleus, which in turn leads to an increase in hydroxy radicals, via the catalytic activity of the Fenton reaction (Lai and Singh 2004).

Our data showed that SMF exposure increased metallothioneins concentration in frontal cortex of rat. These results are similar to those previously reported by Chater et al. (2005) demonstrating that SMF induced metallothioneins synthesis in rat liver. Since these proteins may participate in protection against oxidative stress as a free radical scavenger (Thornalley and Vasak 1985; Juan et al. 1988). Moreover, metallothioneins play a critical role to maintain mineral element homeostasis (Cai et al. 2005). Sub-chronic exposure to SMF failed to increase 8-oxodGuo level in frontal cortex of rat, indicating the absence of DNA oxidation. The integrity of DNA following SMF application may be related to a possible protective role of metallothioneins, against free radical.

Our results suggested that hippocampus structures are the most sensitive to SMF than frontal cortex. Since, the regional specific effect of $S M F$ was registered on the basis of the decrease of CuZn-SOD, Mn-SOD and the increase of MDA concentration in hippocampus. The hippocampus is sensitive to oxidative damage being probably rich in oxidizable substrates and high oxygen tension and low antioxidant capacity. Further experiments, especially investigations of the activation of the antioxidant enzymes' gene expression and trace element homeostasis are needed in order to clarify the precise mechanisms underlying different structure sensitivity after sub-chronic exposure to SMF.

In conclusion, the results presented above showed that sub-chronic exposure to SMF induced oxidative stress in rat frontal cortex and hippocampus. Indeed, we have noted a marked metallothioneins induction, probably implicated in a protective role against DNA oxidative damage in rat brain.

\section{References}

Abdelmelek H., Molnar A., Servais S., Cottet-Emard J. M., Pequignot J. M., Favier R., Sakly M. (2006): Skeletal muscle HSP72 and norepinephrine response to static magnetic field in rat. J. Neural Transm. 113, 821-827; doi:10.1007/s00702-005-0364-7

Aebi H. (1984): Catalase in vitro. Methods Enzymol. 105, 121-126; doi:10.1016/S0076-6879(84)05016-3

Aldrich T. E., Andrews K. W., Liboff A. R. (2001): Brain cancer risk and electromagnetic fields (EMFs): assessing the geomagnetic component. Arch. Environ. Health 56, 314-319

Amara S., Abdelmelek H., Abidi R., Sakly M., Ben Rhouma K. (2005): Zinc prevents hematological and biochemical alteration induced by static magnetic field in rats. Pharmacol. Rep. 57, 616-622

Amara S., Douki T., Ravanat J. L., Garrel C., Guiraud P., Favier A., Sakly M., Ben Rhouma K., Abdelmelek H. (2007): Influence of a static magnetic field $(250 \mathrm{mT})$ on the antioxidant response and DNA integrity in THP1 cells. Phys. Med. Biol. 52, 889-898; doi:10.1088/0031-9155/52/4/002

Bailey W. H. (2002): Health effects relevant to the setting of EMF exposure limits. Health Phys. 83, 376-386; doi:10.1097/ 00004032-200209000-00007

Bauer V., Bauer F. (1999): Reactive oxygen species as mediators of tissue protection and injury. Gen. Physiol. Biophys. 18, (Focus Issue) 7-14

Benzi G., Moretti A. (1995): Age and peroxidative stress-related modifications of the cerebral enzymatic activities linked to mitochondria and glutathione system. Free Radic. Biol. Med. 19, 77-101; doi:10.1016/0891-5849(94)00244-E

Berg H. (1993): Electrostimulation of cell metabolism by low frequency electric and electromagnetic fields. Bioelectrochem. Bioenerg. 31, 1-25; doi:10.1016/03024598(93)86102-7

Cai L., Li X. K., Song Y., Cherian M. G. (2005): Essentiality, toxicology and chelation therapy of zinc and copper. Curr. Med. Chem. 12, 2753-2763; doi:10.2174/ 092986705774462950

Chater S., Abdelmelek H., Sakly M., Ben Rhouma K. (2004): Effects of sub-acute exposure to magnetic field on synthesis of plasma corticosterone and liver metallothionein levels in female rats. Pak. J. Med. Sci. 20, 219-223

Chater S., Abdelmelek H., Couton D., Joulin V., Sakly M., Ben Rhouma K. (2005): Sub-acute exposure to magnetic field induced apoptosis in thymus of female rats. Pak. J. Med. Sci. 21, 292-297

Douki T., Court M., Sauvaigo S., Odin F., Cadet J. (2000): Formation of the main UV-induced thymine dimeric lesions within isolated and DNA as measured by high performance liquid chromatography-tandem mass spectrometry. J. Biol. Chem. 275, 11678-11685; doi:10.1074/jbc.275.16.11678

Eaton D. L., Cherian M. G. (1991): Determination of metallothionein in tissues by cadmium-hemoglobin affinity assay. Methods Enzymol. 205, 83-88; doi:10.1016/00766879(91)05089-E

Ebru B., Mesut A. (2002): The effect of long-term supplemental dietary cadmium on lipid peroxidation and the antioxidant system in the liver and kidneys of rabbits. Turk. J. Vet. Anim. Sci. 26, 1055-1060

Hashish A. H., El-Missiry M. A., Abdelkader H. I., Abou-Saleh R. H. (2008): Assessement of biological changes of con- 
tinuous whole body exposure to static magnetic field and extremely low frequency electromagnetic fields in mice. Ecotoxicol. Environ. Saf. 71, 895-902; doi:10.1016/ j.ecoenv.2007.10.002

Hidalgo J., Campmany L., Borras M., Garvey J. S., Armario A. (1988): Metallothionein response to stress in rats: role in free radical scavenging. Am. J. Physiol. 255, 518-524

Kasai H. (1997): Analysis of a form of oxidative DNA damage, 8-hydroxy-2'-deoxyguanosine, as a marker of cellular oxidative stress during carcinogenesis. Mutat. Res. 387, 147-163; doi:10.1016/S1383-5742(97)00035-5

Lai H., Singh N. P. (2004): Magnetic field induced DNA strand breaks in brain cells of the rat. Environ. Health Perspect. 112, 687-694

Lee B. C., Johng H. M., Lim J. K., Jeong J. H., Baik K. Y., Nam T. J., Lee J. H., Kim J., Sohn U. D., Yoon G., Shin S., Soh K. S. (2004): Effects of extremely low frequency magnetic field on the antioxidant defense system in mouse brain: a chemiluminescence study. J. Photochem. Photobiol., B. 73, 43-48; doi:10.1016/j.jphotobiol.2003.10.003

Maral I., Puget K., Michelson A. M. (1977): Comparative study of superoxide dismutase, catalase and glutathione peroxidase levels in erythrocytes of different animals. Biochem. Biophys. Res. Commun. 15, 1525-1535; doi:10.1016/ S0006-291X(77)80151-4

Nehru B., Anand P. (2005): Oxidative damage following chronic aluminium exposure in adult and pup rat brain. J. Trace Elem. Med. Biol. 19, 203-208

Okano H. (2008): Effects of static magnetic fields in biology: role of free radicals. Front Biosci. 13, 6106-6125; doi:10.2741/ 3141

Ozturk A., Baltaci A. K., Mogulkoc R., Oztekin E. (2003): Zinc prevention of electromagnetically induced damage to rat testicule and kidney tissues. Biol. Trace Elem. Res. 96, 247-254; doi:10.1385/BTER:96:1-3:247

Paoletti F., Mocali A. (1990): Determination of superoxide dismutase activity by purely chemical system based on NAD(P)H oxidation. Methods Enzymol. 186, 209-220; doi:10.1016/0076-6879(90)86110-H

Placer Z. A., Cushman L. L., Johnson B. C. (1966): Estimation of product of lipid peroxidation (malonyl dialdehyde) in biochemical systems. Anal. Biochem. 16, 359-364; doi:10.1016/0003-2697(66)90167-9

Prina-Mello A., Farrell E., Prendergast P. J., Campbell V., Coey J. M. (2006): Influence of strong static magnetic fields on primary cortical neurons. Bioelectromagnetics 27, 35-42; doi:10.1002/bem.20173
Ravanat J. L., Douki T., Duez P., Gremaud E., Herbert K., Hofer T., Lasserre L., Saint-Pierre C., Favier A., Cadet J. (2002): Cellular background level of 8-oxo-7,8-dihydro-2'deoxyguanosine: an isotope based method to evaluate artefactual oxidation of DNA during its extraction and subsequent work-up. Carcinogenesis 23, 1911-1918; doi:10.1093/carcin/23.11.1911

Rollwitz J., Lupke M., Simkó M. (2004): Fifty-hertz magnetic fields induce free radical formation in mouse bone marrow-derived promonocytes and macrophages. Biochim. Biophys. Acta $1674,231-238$

Thornalley P. J., Vasak M. (1985): Possible role for metallothionein in protection against radiation-induced oxidative stress. Kinetics and mechanism of its reaction with superoxide and hydroxyl radicals. Biochim. Biophys. Acta. 827, $36-44$

Trabulsi R., Pawlowski B., Wieraszko A. (1996): The influence of steady magnetic fields on the mouse hippocampal evoked potentials in vitro. Brain Res. 728, 135-139; doi:10.1016/0006-8993(96)00508-2

Wertheimer N., Savitz D. A., Leeper E. (1995): Childhood cancer in relation to indicators of magnetic fields from ground current sources. Bioelectromagnetics 16, 86-96; doi:10.1002/bem.2250160204

Wieraszko A. (2000): Dantrolene modulates the activity of steady magnetic fields on hippocampal evoked potentials in vitro. Bioelectromagnetics 21, 175-182; doi:10.1002/(SICI)1521-186X(200004)21:3<175::AIDBEM4>3.0.CO;2-3

Wolf F. I., Torsello A., Tedesco B., Fasanella S., Boninsegna A., D’Ascenzo M., Grassi C., Azzena G. B., Cittadini A. (2005): 50-Hz extremely low frequency electromagnetic fields enhance cell proliferation and DNA damage: possible involvement of a redox mechanism. Biochim. Biophys. Acta 1743, 120-129; doi:10.1016/j.bbamcr.2004.09.005

Yokus B., Cakir D. U., Akdag M. Z., Sert C., Mete N. (2005): Oxidative DNA damage in rats exposed to extremely low frequency electromagnetic fields. Free Radic. Res. 39, 317-323; doi:10.1080/10715760500043603

Yousef M. I., El-Hendy H. A., El-Demerdash F. M., Elagamy E. I. (2002): Dietary zinc deficiency-induced changes in the activity of enzymes and the levels of free radicals, lipid and protein electrophoretic behaviour in growing rats. Toxicology 175, 223-234; doi:10.1016/S0300483X(02)00049-5

Received: January 16, 2009

Final version accepted: April 7, 2009 